\title{
Reduction of biologics in rheumatoid arthritis: a living systematic review and meta-analysis.
}

\section{Letícia B. Vasconcelos*, Tais F. Galvão}

\section{Abstract}

This living systematic review assesses the effectiveness and safety of reducing or spacing the dose of biological drugs in patients with rheumatoid arthritis at low disease activity, compared to standard dose treatment. Clinical outcomes data were collected and summarized in meta-analysis of standardized mean difference or relative risk. Most outcomes were non-significant.

\section{Key words:}

Rheumatoid arthritis, biologics, dose reduction.

\section{Introduction}

Reduction of biologics after reaching low disease activity rheumatoid arthritis has been tested in clinical trials $^{1}$. The aim of this living systematic review is to assess the effectiveness and safety of the reduction of biologics drugs in patients with rheumatoid arthritis in low disease activity, and to deliver the most update evidence for better decision making.

\section{Results and Discussion}

We searched MEDLINE, Embase, Scopus and The Cochrane Library for randomized controlled trials that reduced or spaced the dose of biologics in patients at low disease activity or remission state compared with maintenance. 1,474 patients were included, from 11 studies selected out of 2155 retrieved publications (last update in July, 2019). We also identified seven eligible ongoing trials, and authors were contacted for data collection.

Risk of bias was high for more than half of studies in blinding of participants, personnel and outcome assessors.

Meta-analysis calculated on Stata showed that outcomes were not significantly different when comparing patients that reduced or maintained the usual dose of biologics (Table).

Evidence quality was rated according to the Grading of Recommendations Assessment, Development, and Evaluation (GRADE) ${ }^{2}$ (Table). More than half of the patients in the meta-analysis came from studies sponsored by the pharmaceutical industry; even though publication bias was not confirmed by Eggers test, the evidence was downgraded. Imprecision also contributed for rating down the evidence

LDA had a significant heterogeneity $\left(I^{2}=55 \%\right)$. In the subgroup meta-analysis, studies that were blinded had no heterogeneity, while it remained high in open label studies $\left(I^{2}=68.6 \%\right)$. The same behavior was seen for adverse events.

Meta regressions were calculated for LDA and $A E$ (outcomes with high heterogeneity), in order to explain the between-study variance of the outcome for continuous covariables. None of the analysis reached statistical significance but trends could be perceived.
Table 1. Summary of findings

\begin{tabular}{|c|c|c|c|}
\hline Outcome & Effect $(95 \% \mathrm{Cl})$ & $\begin{array}{r}\text { Stu } \\
\text { dies } \\
(\mathrm{N})\end{array}$ & $\begin{array}{l}\text { Quality } \\
\text { of } \\
\text { evidence }\end{array}$ \\
\hline \multicolumn{4}{|c|}{ Dichotomous (relative risk) } \\
\hline $\begin{array}{l}\text { Low disease } \\
\text { activity (LDA) }\end{array}$ & $0.90(0.81,1.00)$ & 11 & $\begin{array}{l}\text { Very } \\
\text { low }\end{array}$ \\
\hline $\begin{array}{c}\text { Adverse } \\
\text { events (AE) }\end{array}$ & $1.04(0.93,1.17)$ & 10 & $\begin{array}{l}\text { Very } \\
\text { low }\end{array}$ \\
\hline Serious AE & $0.99(0.70 ; 1.40)$ & 8 & Low \\
\hline \multicolumn{4}{|c|}{ Continuous (standardized mean difference) } \\
\hline $\begin{array}{l}\quad \text { Health } \\
\text { assessment } \\
\text { questionnaire } \\
\text { (HAQ) }\end{array}$ & $\begin{array}{c}0.11(-0.04 \\
0.25)\end{array}$ & 5 & $\begin{array}{l}\text { Very } \\
\text { low }\end{array}$ \\
\hline $\begin{array}{l}\text { Disease } \\
\text { activity score } \\
\text { (DAS-28) }\end{array}$ & $\begin{array}{c}0 \cdot 11(- \\
0.04 ; 0 \cdot 25)\end{array}$ & 7 & $\begin{array}{l}\text { Very } \\
\text { low }\end{array}$ \\
\hline $\begin{array}{l}\text { Radiographic } \\
\text { Progression }\end{array}$ & $\begin{array}{c}0.06(-0.27 \\
0.14)\end{array}$ & 1 & Low \\
\hline $\begin{array}{l}\text { Patient global } \\
\text { assessment } \\
\text { (PGA) }\end{array}$ & $\begin{array}{l}0.14(-0.01 \\
0.30)\end{array}$ & 2 & Low \\
\hline Time to flare & $\begin{array}{lll}2.23 & (-2 \cdot 87 ; \\
1.6) & & \\
\end{array}$ & 1 & Low \\
\hline
\end{tabular}

\section{Conclusions}

Available evidence shows no differences in clinically relevant outcomes from reduction of biologics compared to regular doses. The limited number of studies and the low certainty of evidence reduce the confidence in the findings, which needs to be monitored to better inform patients and clinicians.

\section{Acknowledgement}

The authors thank Jessica Q. Pereira and Marcus T. Silva for the contribution data extraction and risk of bias assessment.

11. Van Herwaarden, Noortje et al. Down-titration and discontinuation strategies of tumor necrosis factor-blocking agents for rheumatoid arthritis in patients with low disease activity. Cochrane Database Syst Rev, 2014;29(9):CD010455.

2. Guyatt GH, Oxman AD, Vist GE, et al. GRADE: an emerging consensus on rating quality of evidence and strength of recommendations. BMJ 2008;336(7650):924-26. 